\title{
Viral Infection in Primary Antibody Deficiency Syndromes
}

Running Head: Viral Infection in PAD Syndromes

Authors:

Timothy P W Jones ${ }^{1}$

Matthew Buckland²

Judith Breuer ${ }^{3}$

David M Lowe ${ }^{2}$

1. Department of Infectious Disease and Microbiology, Royal Free Hospital, Pond Street, London, NW3 2QG, United Kingdom.

2. Institute of Immunity and Transplantation, Royal Free Campus, University College, London, NW3 2QG, United Kingdom

3. Division of Infection and Immunity, University College London, London, WC1E 6BT, United Kingdom

\section{Corresponding Author:}

Dr David M Lowe

Institute of Immunity and Transplantation, University College London,

Royal Free Campus,

London,

NW3 2QG,

United Kingdom

d.lowe@ucl.ac.uk

Keywords:

Primary Immune deficiency, Immunodeficiency, Enterovirus, Herpesvirus, Norovirus 


\section{Summary}

Patients with Primary Antibody Deficiency syndromes such as X-linked agammaglobulinemia (XLA) and common variable immunodeficiency (CVID) are at increased risk of severe and invasive infection. Viral infection in these populations has been of increasing interest as evidence mounts that viruses contribute significant morbidity and mortality: this is mediated both directly and via aberrant immune responses. We explain the importance of the humoral immune system in defence against viral pathogens before highlighting several significant viral syndromes in patients with antibody deficiency.

We explore historical cases of Hepatitis C via contaminated immunoglobulin products, the predisposition to invasive enteroviral infections, prolonged excretion of vaccine-derived poliovirus, the morbidity of chronic norovirus infection and recent literature revealing the importance of respiratory viral infections. We discuss evidence that herpesviruses may play a role in driving the inflammatory disease seen in a subset of patients. We explore the phenomenon of within-host evolution during chronic viral infection and the potential emergence of new pathogenic strains. We highlight novel and emerging viruses identified via deep sequencing techniques. We describe the treatment strategies that have been attempted in all these scenarios and the urgent outstanding questions for research. 


\author{
Abbreviations \\ ADCC - Antibody Dependent Cellular Cytotoxicity \\ CDC - Complement-dependent cytotoxicity \\ $\mathrm{CH}$ - Congenital Hypogammaglobulinaemia \\ CVID - Common Variable Immunodeficiency \\ FFP - Fresh Frozen Plasma. \\ GLILD - Granulomatous Lymphocytic Interstitial Lung Diseases \\ HIgM - Hyper IgM Syndrome \\ HLH - Haemophagocytic Lymphohistiocytosis \\ IMIg - Intramuscular Immunoglobulin \\ IVIg - Intravenous Immunoglobulin \\ TLR - Toll Like Receptor \\ XLP1 - X-linked lymphoproliferative syndrome type 1 \\ XLA - X-linked agammaglobulinaemia
}




\section{Introduction}

Patients affected by both primary and secondary immune deficiencies have a greater incidence and severity of viral disease. ${ }^{1}$ Certain immunodeficiency disorders primarily affecting cytokine production and T cell differentiation particularly predispose to viral infection. For example, Xlinked lymphoproliferative syndrome type 1 (XLP1) associated with aberrant T and NK-cell cytokine production ${ }^{2}$ has a strong association with Epstein Barr Virus (EBV): infection results in severe mononucleosis and haemophagocytic lymphohistiocytosis (HLH) with an increased incidence of EBV-associated B-cell lymphomas. ${ }^{3,4}$ Mutations in Toll Like Receptor (TLR) pathways predispose individuals to herpes simplex virus 1 encephalitis, ${ }^{5}$ and inefficient IFN production is thought to contribute to the disseminated human papillomavirus infections seen in WHIM syndrome (warts, hypogammaglobinaemia, infections and myelokathexis (white cells retained in bone marrow)). ${ }^{6}$

While there has been significant interest in conditions which affect $T$ cell function, much less emphasis has been placed on the role of viral infection in primary antibody deficiency syndromes. These conditions constitute the majority of severe immunodeficiency seen in adult clinical practice.

Antibodies have an important role in the immunological response to viral infection, highlighted by their well-recognised importance as a marker of successful vaccination against many viruses. Antibodies exert their effect through a variety of mechanisms; the most fundamental of these is 'neutralisation' of free virions. ${ }^{7}$ Neutralisation is mediated by several processes, and there remains discussion over which mechanism is the most significant. ${ }^{7,8}$ Inactivation of viral 
proteins, induction of conformational change and directly blocking entry into target cells have all been described ${ }^{8}$, while there is also evidence that bound immunoglobulin prevents viral uncoating of any internalised virus-antibody complexes. ${ }^{9}$ Bound antibody also activates complement which may both coat the viral surface leading to agglutination ${ }^{10}$ but also, in the case of enveloped viruses, directly mediate virolysis. ${ }^{7}$ Agglutination of viral complexes via antibody and complement binding also prevents infection of target cells and aids phagocytosis by professional phagocytes: this is in turn enhanced via binding of the Fc component of bound antibody to phagocyte Fc receptors and by complement components binding to complement receptors. Once internalised by professional phagocytic cells, viruses undergo degradation in the phagolysosome. Antibodies also have a role in the response to virally infected cells, preventing release of new virions, ${ }^{11}$ while binding to viral proteins expressed on the surface of infected cells can lead to cell lysis through antibody dependent cellular cytotoxicity (ADCC) or complement-dependent cytotoxicity (CDC). ${ }^{12}$ Figure 1 summarises the various mechanisms by which antibodies defend against viral infection.

[Figure 1. To be inserted here]

\section{Primary antibody deficiency syndromes}

Common variable immunodeficiency (CVID) is the most prevalent severe inherited antibody deficiency syndrome. ${ }^{13}$ Although a discussion on the various forms of this condition and the underlying immunology is beyond the scope of this manuscript, a failure of B-cell differentiation 
is a key component resulting in reduced secretion of immunoglobulins. ${ }^{14}$ Importantly, the disease is often associated with, or indeed may result from, defects in T cell function. ${ }^{13,15,16}$

X-linked agammaglobulinaemia (XLA, Bruton's Disease) results from a mutation in the Btk gene encoding a tyrosine kinase responsible for B-cell differentiation. ${ }^{17}$ The result is an absence of circulating B cells and an inability to produce gamma globulin. XLA usually presents in early childhood with recurrent bacterial infections which are often sino-pulmonary. ${ }^{1} \mathrm{CVID}$ presents with similar infections as well as autoimmune and inflammatory complications, and often presents in older children, adolescents or adults.

In this review we look at the current understanding of viral infections in these conditions and explore their significance for affected patients and more widely on public health.

\section{Enteroviruses}

Enteroviruses are members of the Picornaviridae family, separated into over 100 serotypes containing the polioviruses, group A and B coxsackieviruses and echoviruses among others. ${ }^{18}$ Occurring throughout the year in temperate climates, transmission is largely faeco-oral, making household contacts particularly susceptible as well as those with poor sanitary conditions. Immunity to enteroviruses is largely antibody mediated, ${ }^{19}$ and severe and chronic enterovirus infections have a long established association with low antibody levels. 
Prolonged excretion of poliovirus following infection or live vaccination of patients with antibody deficiency was first reported in $1971 .{ }^{20}$ Although there is no clear evidence that this results in increased severity of enteral invasive infection, prolonged shedding results in greater risk of developing the neurological sequelae of polio. ${ }^{21} \mathrm{It}$ is also a fundamental public health concern, heightened by reports of pathogenic mutations of the oral polio vaccine virus occurring within long-term carrier hosts. ${ }^{21-24}$ Viral shedding has been identified in stool samples of CVID patients for as long as 5.5 years following vaccination, ${ }^{23}$ and is likely to persist for far longer in some. Kew et al. using modelling of sequence mutations have reported shedding occurring more than 9 years after vaccination. ${ }^{25}$

Concern regarding the role of long term excretors of vaccine-derived mutated strains of polio destabilising worldwide vaccination programs has prompted extensive investigation. Of 942 patients with symptoms suggestive of immunodeficiency in Sri Lanka, 5 were found to be asymptomatically secreting poliovirus, two of whom were subsequently discovered to have CVID or XLA. ${ }^{26}$ However, most antibody-deficient patients do seem to clear vaccine mediated virus efficiently. A survey of patients with diagnosed immunodeficiency in the Americas and United Kingdom revealed only 4 patients secreting vaccine derived strains, despite the majority previously receiving oral polio vaccine. ${ }^{27}$ Although a relatively rare complication, these findings nevertheless questioned the safety of ongoing vaccination with live attenuated strains of polio, particularly in settings where early diagnosis of immunodeficiency was likely to be difficult. This was integral to the change in global vaccination strategy towards inactivated vaccination. Attempts to model the prevalence of vaccine-derived polio excretors in primary immunodeficiency patients have suggested approximately 30 chronic excretors exist 
worldwide, most in middle income countries. ${ }^{28}$ Groups have highlighted the risk of outbreaks after the cessation of oral vaccination programs, and the need for containment plans to be formulated. However the difficulty in identifying long-term excretors or effectively treating them, as well as a lack of prevalence figures in low-income countries, makes modelling challenging and is a concern in estimating the end date of vaccination programs.

It is thought that treatment with Intravenous immunoglobulin (IVIg) prevents neurological sequelae, ${ }^{26}$ however complications have been reported despite effective immunoglobulin replacement. ${ }^{29}$ Conversely, cases of non-fatal wild-type polio infection in the absence of immunoglobulin replacement have also been reported. ${ }^{30,31}$

Effective antiviral treatment of chronically excreting patients has not been extensively trialled. One group used post-colostral breast milk in a patient with CVID. Despite effective in-vitro neutralisation this did not eliminate the virus, likely due to insufficient delivery of a therapeutic dose. ${ }^{20}$ Antivirals have been studied for their effect on reducing shedding times in immunocompetent individuals. A blinded placebo-controlled trial of pocapavir, a viral capsid inhibitor, revealed reduced shedding time in healthy patients vaccinated with oral polio vaccine. ${ }^{32}$ However, resistant viruses rapidly emerged suggesting that monotherapy may not be suitable in chronically infected immunosuppressed populations. Instead it is likely that combination therapy would be required with other antivirals known to also have activity against polio such as $\mathrm{V}-7404,{ }^{33}$ or possibly fluoxetine which appears to have antiviral activity against Enterovirus D68. ${ }^{34}$ 
IgA has been shown to be particularly important in poliovirus inactivation; despite effective IPV vaccination of IgA deficient patients, prolonged viral shedding in stool has been reported after subsequent oral live-attenuated vaccination. ${ }^{35}$ However, patients with selective IgA deficiency - a fairly common finding - are thought unlikely to be at risk of extremely prolonged shedding of poliovirus.

\section{Chronic Enterovirus Meningoencephalitis}

Cases of chronic meningoencephalitis secondary to enterovirus infection have been recorded for as long as XLA has been described ${ }^{36}$, and are also occasionally seen in CVID. Table 1 summarises reported cases in the literature. As well as poliovirus, echoviruses have been significantly associated with a severe course and in many cases death. ${ }^{37-42}$ Several echovirus serovars have been implicated but echovirus 11 is the most common. ${ }^{43}$ Case reports of Coxsackie $A$ and $B$ have also been reported. ${ }^{37,44}$

[Table 1. To be inserted here]

Enterovirus meningoencephalitis carries a high mortality. A case-series of 13 patients in a British cohort reported death in 6 of the 7 cases with confirmed viral disease. ${ }^{38} \mathrm{~A}$ review of published cases conducted by Halliday et al. found that almost half (31 of 72) of patients with non-polio entroviral CNS infections had died, a proportion they surmised was underreported due to short follow-up in most cases. ${ }^{43}$ 
The chronicity and inability to successfully clear virus from the CSF is seen much more frequently in XLA than other antibody deficient syndromes such as CVID ${ }^{38,43-45}$ and X-linked hyper IgM syndrome ${ }^{42,43}$ although the reason for this remains unclear. ${ }^{37}$ Despite the prolonged faecal shedding times associated with poliovirus the same is not seen with echoviruses, suggesting that recurrent autoinfection is unlikely to be responsible for the chronicity.

Although meningoencephalitis can precede the diagnosis of XLA and therefore adequate immunoglobulin replacement, there remain cases of patients receiving antibody replacement who develop infection. ${ }^{37,38}$ The apparent inefficacy of IgG replacement in these cases may be due to inadequate supplementation; the optimal trough (nadir) level required for prevention has not been established but many centres aim for a trough level of $>10 \mathrm{~g} / \mathrm{L}$ in $\mathrm{XLA}$, (albeit the evidence for this is largely based upon bacterial chest infections) ${ }^{46}$ The role of IVIg in treatment of active infection is less clear. Although several case reports cite clinical improvement and viral clearance in some patients treated with IVIg, ${ }^{47,48}$ larger reviews suggest that no therapy has a meaningful impact on survival. ${ }^{43}$ Intrathecal administration of immunoglobulin has also been attempted in non-responders, with some benefit reported ${ }^{38,42,49}$ but failure is common and the procedure is not without risk. ${ }^{50}$ Antivirals, most notably pleconaril, have also been reported to confer some benefit ${ }^{45}$ but are not widely available. In all studies of treatment, the small number of cases makes powering for meaningful effect sizes difficult. As with poliovirus, pocapavir may hold some promise, ${ }^{50}$ but again combination therapy may be preferred. Clinical trials to adequately investigate combination therapy should ideally have a factorial design; however, numbers of patients are so limited that this is extremely difficult to achieve. 


\section{Respiratory Viruses}

Although recurrent respiratory infection with bacterial pathogens is a common presenting feature in the primary antibody deficiency syndromes, respiratory viruses have only been investigated more recently.

A survey of respiratory infections in CVID patients found that respiratory viruses were present in $56 \%$ of exacerbations, ${ }^{51}$ the most common being rhinovirus. However, the role of viruses in unilaterally driving exacerbations was less clear with bacterial and viral coinfection present in 25\%. Similar findings have been found in other centres in both XLA and CVID patients, ${ }^{52,53}$ with rhinovirus again the predominant species and those infected showing prolonged viral shedding. However, infection with adenovirus, respiratory syncytial virus (RSV), human metapneumovirus, influenza and parainfluenza have also been reported in surveys. ${ }^{51-54}$ of note, influenza has not been reported to manifest frequent or particularly severe presentations in patients with primary antibody deficiency syndromes. This may relate in part to the current recommendation to vaccinate patients with primary immunodeficiency against influenza. ${ }^{55}$ Although patients with XLA or CVID are unable to produce the neutralising antibodies thought to be responsible for vaccine immunity, it is believed that the T-cell response stimulated by influenza vaccination ${ }^{56-58}$ is likely to be intact. Vaccination of household contacts is also recommended to generate a localised herd immunity effect. ${ }^{59}$ 
Rhinovirus shedding is prolonged in CVID and XLA

Prolonged rhinovirus shedding times have been noted in several studies. ${ }^{52,60,61}$ Compared to controls, Peltola et al. reported average shedding times as three times longer in immunodeficient cases (10.1 v 31 days) and as long as 5 months in the case of one patient. ${ }^{60}$ Of note, these patients had adequate IgG replacement, perhaps suggesting a role for IgA (or IgM) secretion in preventing chronicity. Indeed in a survey of adult primary immunodeficiency patients, low levels of IgA were significantly associated with having a positive virology result. ${ }^{53}$ Alternative explanations would be impaired secretion or transport of IgG from the bloodstream to the respiratory tract, or inadequate titres of specific neutralising antibodies in the infused immunoglobulin products.

The relationship between increased shedding time and severity of illness is more difficult to quantify. Although studies have reported prolonged symptoms in patients with persistent shedding, ${ }^{60}$ illness duration can be difficult to causally link to a single pathogen as patients often suffer chronic or recurrent respiratory symptoms. Perhaps of more concern is the potential for evolution of novel or virulent strains of virus within a chronically infected host, as discussed above for enterovirus.

Increased severity of respiratory viral infections has not been clearly reported, with a Japanese nationwide survey reporting a low incidence of admission with viral infection in antibody deficient patients. ${ }^{54}$ Conversely, asymptomatic respiratory viral shedding has been reported, with rhinovirus and enterovirus isolated from maxillary sinus fluid of asymptomatic patients. ${ }^{62}$ Bronchoscopic washings also commonly reveal viruses, with $29 \%$ of apparently asymptomatic 
patients testing positive for adenovirus. ${ }^{63}$ The significance of this remains debatable, although a role for viral antigens in the development of interstitial lung diseases in CVID has been suggested ${ }^{64}$ (see below). It should be noted that the increased availability and use of high fidelity PCR for respiratory viruses in recent years has improved sensitivity and apparent prevalence, but these assays cannot assess viral viability or prove pathogenicity.

Viral infection of the respiratory tract may precede bacterial infection or be associated with bacterial dysbiosis and therefore respiratory viruses could have a role in driving bacterial exacerbations. ${ }^{65,66}$ Furthermore, viral respiratory tract infection in itself can drive neutrophilic inflammation, ${ }^{67}$ and might therefore contribute to progressive bronchiectasis. Consequently, whether positive viral swabs should instruct antibiotic cessation is unclear and has not yet been recommended, with other measures such as sputum purulence being a better marker of rapid response to antibiotics. ${ }^{51,53}$ Treatment of prolonged shedding is equally questionable. Although a case series of 4 patients treated with pegylated IFN A2a and ribavarin achieved clearance and self-reported improvement in quality of life, these drugs have significant potential side effects and all patients became re-infected within two to twelve months after therapy. ${ }^{61}$ Further exploration of respiratory viral infections is needed to clarify their full significance in primary antibody deficiency syndromes.

\section{Norovirus}

Norovirus is a member of the Caliciviridae family of RNA viruses. ${ }^{68}$ Cases tend to arise in epidemics of gastroenteritis, ${ }^{69,70}$ or endemically in some settings. ${ }^{70}$ Transmission is faeco-oral, 
although airborne and fomite spread from vomitus is also possible, and consequently outbreaks in healthcare environments can be challenging to control. ${ }^{71}$

In one survey of immunodeficient patients norovirus was the most common gastrointestinal virus found. ${ }^{53}$ This survey also found persistent excretion as described above with other viruses.

Persistent norovirus infection and relationship to 'CVID Enteropathy'

Prolonged shedding times of norovirus have been reported by several studies in both symptomatic ${ }^{72,73}$ and apparently asymptomatic individuals ${ }^{53}$ with CVID. Shedding times have been reported by others as long as 1200 days with serial positive faecal samples and gastrointestinal biopsies ${ }^{74}$, while we have recently described a patient infected with the US95/96 strain of norovirus (which circulated until 2002) who was still excreting virus in $2017 .{ }^{75}$ Of particular interest in this regard is the potential association of norovirus with 'CVID enteropathy'. This term has been used to describe various pathological entities in CVID patients with diarrhoea, including non-specific colitis or inflammation resembling classical inflammatory bowel disease. However, the term is probably best reserved for patients presenting with malabsorption and villous atrophy, often with intraepithelial lymphocytosis, of unknown cause.

${ }^{76}$ Despite histological similarities to coeliac disease, patients do not respond to gluten

withdrawal. ${ }^{74}$ Affecting approximately $5 \%$ of patients with CVID it is particularly associated with 
T-cell defects. ${ }^{77}$ In some cases the dietary losses encountered can require treatment with parenteral nutrition. ${ }^{53}$

Several groups have found CVID enteropathy to be associated with chronic norovirus infection, 53,72 and indeed Woodward et al. treated a cohort of 8 patients with ribavirin, two of whom showed viral clearance. Paradoxically, other groups have reported clinical response to anti-TNF therapies ${ }^{78}$ and steroids, ${ }^{76}$ although histological response to these therapies has not been documented. ${ }^{78}$ Recently, we have treated a patient with the novel antiviral favipiravir and observed marked changes in the dominant viral haplotype as well as accelerated mutagenesis in minority variants, coinciding with clinical response. ${ }^{75}$ Another potential treatment under evaluation is nitazoxanide, currently being formally evaluated in post-stem cell transplant patients in the United States. ${ }^{79}$ While the use of oral IVIg and colostral breast milk has been used with some success in solid organ transplant recipients, ${ }^{80}$ this approach has not been proven effective in patients with primary immunodeficiency. ${ }^{73}$

Concurrent evidence of other viral pathogens such as parechovirus ${ }^{81}$ together with norovirus has also been reported in patients with 'CVID enteropathy'. Conversely, one study investigating enteropathy in CVID found no evidence in norovirus in stool or biopsy samples in a patient with villous atrophy or a further thirty-one with evidence of increased intraepithelial leucocytes but no evidence of villous atrophy. ${ }^{82} \mathrm{~A}$ recent study on CVID enteropathy found low levels of norovirus in biopsies of some patients but also identified enteropathy patients without norovirus. ${ }^{83}$ The authors of this study implicate a bacterial pathogen instead. It remains to be seen therefore if norovirus is the sole pathogen, or one of many, driving intraepithelial 
lymphocyte accumulation and villous atrophy - or indeed whether the mechanism is independent of pathogens in some individuals. We have previously reviewed norovirus infection in primary immunodeficiency in more detail. ${ }^{73}$

\section{Herpesviruses}

The Herpesviridae are a family of DNA viruses responsible for a wide range of human diseases. Several members of this family cause significant invasive disease in patients with $T$ cell impairment. ${ }^{1}$ However the impact of these viruses on primary antibody deficiency disorders is less clear.

Cytomegalovirus infection may be under-reported

Cytomegalovirus (CMV) is an enveloped double stranded DNA virus. Infection results in a spectrum of illness depending on host immunity, ranging from infectious mononucleosis to sight-threatening retinitis or an enteritis which carries a significant mortality and morbidity. ${ }^{84,85}$ Several case studies have described severe CMV disease in patients with CVID. ${ }^{86-91} \mathrm{CMV}$ colitis was the most frequent severe manifestation, ${ }^{86-90}$ characterised by symptomatic diarrhoeal disease with histological evidence of CMV inclusions. Long term outcome was not recorded in all cases but infection caused significant morbidity, with one death reported. ${ }^{88}$

CMV can cause a pneumonitis, but the significance of finding CMV DNA in respiratory samples of patients without pulmonary inflammation is doubtful, and even in the presence of 
pathological lung changes remains unclear. Higher viral loads of CMV have been used to differentiate shedding from pneumonia in haematopoietic stem cell transplant recipients, ${ }^{92}$ but whether this can be generalised to CVID, where CMV in the lung has been more implicated in inflammatory interstitial disease than as a cause of acute infection, is unknown.

Furthermore, even in patients with 'true' infection the relevance of CVID in terms of risk for severe disease is less clear; several of the patients described in reports were also receiving immunosuppressive therapies ${ }^{87-89}$, which are known to independently predispose to severe invasive CMV disease, ${ }^{93}$ while others did not include current or recent management. ${ }^{90,91}$ In addition, several more profound cell signalling defects have recently been identified which, although potentially diagnosed as CVID due to hypogammaglobulinemia, actually confer a combined immune deficiency phenotype with functional T cell impairment. ${ }^{94}$ Such defects can confer a greater risk of severe viral infection and in particular CMV infection, thus misclassification of primary immune deficiency may partially explain the severe presentations described in the literature. We have not identified any published case reports of severe CMV related diseases in XLA, perhaps suggesting that antibody deficiency alone is insufficient to confer significant risk of this infection.

It has nevertheless been suggested that there may be under-reporting of CMV infection in CVID. One study found severe CMV disease in $10 \%$ of a CVID cohort ${ }^{89}$; however a larger study found only $5 \%$ of CVID patients were CMV positive on blood nested PCR, none of whom had evidence of active disease. ${ }^{95} \mathrm{~A}$ similar sized study reporting CMV PCR positivity of enteral biopsies in CVID patients found a similar prevalence $(4.7 \%)^{82}$, but none of these patients 
showed evidence of enteritis on histology. This apparently low cross-sectional prevalence suggests that CMV is controlled adequately in most CVID patients. However, accurate reporting of previous infection is difficult in this patient population as serology is unreliable. ${ }^{96}$

CMV may be implicated in inflammatory disease in CVID

CMV was once posited as a viral cause of CVID, in part due to the hypogammaglobulinemia seen in some cases of infection, ${ }^{97}$ although this has since been discounted. ${ }^{95}$ There is however a suggestion that CMV may have a role in abnormal modulation of T-cell responses. Several studies have shown that the T-lymphocytes of CVID patients demonstrate increased response to CMV antigens compared to controls. ${ }^{98,99}$ Raeiszadeh et al. discovered that, in the $55 \%$ of CVID patients with CMV-reactive CD8+ T-cells, the frequency of reactive cells was thirteen-fold greater than controls when exposed to antigen. Release of Interferon gamma (IFN-Y) and tumor necrosis factor-A (TNF-A) from activated CD4+ T-lymphocytes and perforin from CD8+ Tlymphocytes were also significantly increased in response to CMV peptides, while the ratio of CD4:CD8 was decreased. ${ }^{98}$ The group suggested that a subset of CVID patients with these exaggerated responses to CMV may be an increased risk of severe disease. However, a causal relationship could not be elucidated and it may be simply that CVID patients with T-lymphocyte activation, a well-recognised subset, mount an exaggerated response to many viral agents.

Marashi et al. demonstrated a significant association between CMV infection (as evidenced by responses in CD4+ and CD8+ T cells to CMV antigen) and inflammatory complications in CVID. They also highlighted a reduction in CD73+CD8+ cells; a subset associated with anti- 
inflammatory properties. ${ }^{99,100}$ A follow-up study highlighted that this effect was not seen with EBV, and demonstrated that late effector populations of CD8+ T-cells were particularly expanded ${ }^{101}$, a group of cells associated with chronic infection. ${ }^{102}$ TNF-A and IFN-Y secretion are important in proliferation of these cells, which was postulated to explain the symptomatic response of a cohort of CVID patients with inflammatory complications to anti TNF-A treatments. ${ }^{78}$ No randomised studies of CVID patients exhibiting chronic inflammatory complications have trialled the use of ganciclovir to assess the hypothesis that CMV is the causative agent. As with enteropathy, it is possible that other infectious agents may also be implicated, or perhaps the enhanced immunological response to CMV is simply an epiphenomenon in patients with chronic inflammation.

Other herpesviruses are less implicated in disease in antibody deficiency syndromes

Evidence for a significant role of EBV in humoral immunodeficiency is scant. While EBV has been isolated from enteral tissue biopsy in CVID ${ }^{82}$ there was no obvious association with gastrointestinal disease. Lymphoma is more common in CVID than the general population, leading to suggestions for a significant role of viruses with oncogenic potential. ${ }^{103}$ There are cases of malignancy in antibody deficient patients with evidence of EBV in tissue samples. ${ }^{104-106}$ However, there is limited evidence that EBV-related malignancy is more common in CVID patients, with instead a preponderance of extranodal EBV-negative B cell lymphomas. ${ }^{103,107}$ In thirty samples from CVID patients presenting with lymphoproliferative lesions, 5 were found to be positive EBV DNA on in-situ hybridisation, of which only one was malignant. ${ }^{108}$ 
Human herpesvirus 8 has been implicated in the development of granulomatous lymphocytic interstitial lung diseases (GLILD), an inflammatory disease process seen in up to $20 \%$ patients with CVID. Those affected show an increased incidence of T-cell lymphopenia, splenomegaly and B cell lymphoproliferative disorders. ${ }^{109}$ Wheat et al. found two thirds of patients with GLILD were PCR positive for HHV-8 on peripheral blood samples, significantly higher than CVID controls. ${ }^{110}$ No other viruses were tested for and in light of the findings described above, CMV may have been an important omission. Although not reported elsewhere, this suggests that more than one herpesvirus may be associated with chronic inflammation in CVID.

More atypical presentations of herpesvirus disease have been recorded in only small numbers; human herpesvirus -7 has been reported in one case study to have caused veno-oclusive disease resulting in hepatic failure in a patient with $\mathrm{XLA},{ }^{111}$ and herpes simplex virus type 1 (HSV-1) has been associated with colitis in CVID. ${ }^{112}$ In both cases it is difficult to be certain that these pathogens were the only factors in the respective presentations. More typical manifestations of these infections have not been extensively reported, although recurrent cold sores, genital herpes and shingles are noted in clinical practice in a minority of individuals.

\section{Hepaciviruses}

Hepaciviruses are positive-sense single-stranded RNA viruses of the Flaviviridae family. Hepacivirus $C$ includes hepatitis $C$ virus which is responsible for a large proportion of cases of chronic hepatitis worldwide. ${ }^{113}$ This virus has been extensively investigated in the context of 
primary antibody immunodeficiency as high profile cases of contaminated blood products including IVIg historically resulted in a significant number of iatrogenic cases. ${ }^{114}$

Hepatitis $\mathrm{C}$ infection from contaminated blood products results in more severe disease in patients with antibody deficiency

Several groups have reported on the follow-up of patients with CVID and XLA infected iatrogenically with hepatitis C. ${ }^{115-120}$ Cohorts from Norway ${ }^{115,116}$, the UK ${ }^{118}$ and Spain ${ }^{119}$ have reported significantly increased mortality and morbidity in primary antibody disorders compared to other cases of iatrogenic hepatitis C. Borjo et al reported a 10 year mortality of $20 \%$ and evidence of cirrhosis in $80 \%$ of patients with CVID despite attempted treatment. ${ }^{116}$ By fifteen year follow-up $83 \%$ of patients with CVID had died, while all-patient mortality was $50 \%$, 115 comparing unfavourably to a reported mortality of $13 \%$ of those infected in the general population at the time. ${ }^{121}$ Similar findings were made in a UK cohort which reported $24 \%$ reaching end-stage liver disease within 5 years and a mortality rate of $32 \% .{ }^{118}$

Other groups have not reported such a high mortality in primary antibody deficiency disorders. 117,122 In an Italian cohort, Quinti et al reported that none of the 18 HCV-DNA positive patients had evidence of severe disease, with only a third of the CVID patients showing cirrhosis and no deaths, although follow-up was shorter with only 6 patients reaching a 10 year follow up period by the time of publication. ${ }^{122} \mathrm{~A}$ retrospective survey of 58 cases of HCV in the USA reported a mortality rate of $23 \%$ in CVID patients. Resolution occurred in a third of the patients undergoing treatment with $20 \%$ of those not treated resolving spontaneously. ${ }^{117}$ 
Although treatment protocols and rates of treatment completion were variable between studies, all groups reported improved outcomes in those treated for infection. There was heterogeneity in these findings with clearance reported between $17 \%^{115}$ and $40 \%{ }^{118}$. It must be noted that due to the publication period of these findings the majority of patients were treated with IFN monotherapy with a minority also receiving ribavirin. Table 2 summarises reports of hepatitis $\mathrm{C}$ infection in antibody-deficient patients.

[Table 2. To be inserted here]

It remains unknown whether the mechanism of exposure or the underlying immunological condition is more significant in influencing disease severity in primary antibody deficiency states, but both may be important. A significant number of patients were infected with multiple HCV genotypes in the Norwegian cohort ${ }^{115}$, a factor reported to be responsible for poorer outcome and increased complication. ${ }^{123,124}$ No studies have been reported focussing upon CVID patients infected with hepatitis $C$ through means other than immunoglobulin exposure, although a case study in the era prior to IVIG suggested that rapid and severe disease can occur after natural infection with hepatitis $B$ virus ${ }^{125}$. Furthermore, hepatitis $B$ reactivation and infection severity has been shown to be significantly increased in those treated with Rituximab, ${ }^{126}$ an agent which targets antibody production via CD20 B cells; however, it is unclear if there is a significantly increased mortality. ${ }^{127}$ In prevalence studies completed in the wake of contaminated blood products, there was not a significant number of asymptomatic patients carrying viral hepatitis viruses. ${ }^{128}$ Of note, there was a discrepancy between countries 
on the testing and use of pooled serum prior to molecular testing for HCV viral RNA. ${ }^{129}$ In excluding all pools containing HCV antibody positive donors, physicians in the US may have inadvertently increased infection incidence or severity compared to pools containing potentially neutralising antibody, although this remains unproven.

There is some evidence that disease severity is not uniform between different antibody deficient disorders. Patients with XLA were reported to have lower rates of cirrhosis than those with CVID in the Norwegian cohort ${ }^{115}$, while the mortality rate of XLA and hyper IgM patients in the American cohort was also lower at $8 \%$ versus $23 \%$ at 6 years. ${ }^{117}$ Due to the small number of patients this did not reach statistical significance, so this apparent discrepancy requires further evaluation. However, as noted above, patients with CVID frequently suffer aberrant inflammatory responses. Correspondingly, chronic liver inflammation in CVID even in the absence of hepatotropic viral infection is well documented (usually as granulomatous hepatitis or nodular regenerative hyperplasia) and is observed to progress to cirrhosis in some cases. ${ }^{130}$

Other chronic viral hepatitides are described less commonly in these patient cohorts. We recently screened our antibody-deficient patients for the presence of chronic hepatitis $E$ but identified no patients, which may correlate with the presence of efficient neutralising antibody in many of the infused immunoglobulin products. ${ }^{131}$

Similarly, all patients on immunoglobulin replacement test positive for hepatitis B surface antibody. ${ }^{96}$ A significant proportion also test positive for hepatitis B core antibody (HBV cAb) due to passive transmission of antibody, which confounds tests for prior infection. ${ }^{96}$ 


\section{Novel and emerging viruses}

More recently, deep sequencing techniques have enabled the accurate identification of viral genetic material in clinical samples, implicating novel pathogens as causes of disease in immunodeficient patients. Encephalitis in XLA patients has been reported due to a newly described astrovirus ${ }^{132}$ and to Cache valley virus, ${ }^{133}$ while a child with XLA has been found to have chronic disseminated infection with Aichi virus, ${ }^{134}$ an enterovirus. These diagnostic techniques are likely to continue to identify important viral infections in these populations over coming years.

\section{Conclusions}

Although primary antibody deficiency syndromes confer significant risk of invasive bacterial infections, the role of viruses should not be ignored. Although not all viral agents cause severe infections, there are many pathogens which carry a risk of morbidity and, particularly in the case of enterovirus, mortality for patients with CVID and XLA. Evidence is also mounting that viral agents may have a role in several of the inflammatory complications of CVID. Conventional prophylactic treatment strategies with immunoglobulins are not always effective, while treatment options for chronic or invasive viral disease are limited and often ineffective.

Of especial public health concern is the phenomenon of within-host evolution during chronic infection with the potential development of novel strains or virulence factors. There is a need for further research into appropriate antivirals and novel therapeutics. The emergence of novel 
viruses may also be a particular threat to this cohort of patients and warrants ongoing vigilance. The ubiquitous and diverse nature of these infectious agents means that effective management will continue to present a therapeutic dilemma. 
Conflict of interest statement: DML has received travel and subsistence costs for (unpaid) consultancy work from CSL Behring. Other authors have no conflicts of interest to declare. 


\section{Bibliography}

1. Dropulic LK, Cohen JI. Severe Viral Infections and Primary Immunodeficiencies. Clinical Infectious Diseases. 2011;53(9):897-909.

2. Veillette A. Immune Regulation by Slam Family Receptors and Sap-Related Adaptors. Nature Reviews Immunology. 2006;6(1):56-66.

3. Coffey AJ, Brooksbank RA, Brandau O, et al. Host Response to Ebv Infection in X-Linked Lymphoproliferative Disease Results from Mutations in an Sh2-Domain Encoding Gene. Nature Genetics. 1998;20(2):129-135.

4. Harrington DS, Weisenburger DD, Purtilo DT. Malignant-Lymphoma in the X-Linked Lymphoproliferative Syndrome. Cancer. 1987;59(8):1419-1429.

5. Zhang SY, Jouanguy E, Sancho-Shimizu V, et al. Human Toll-Like Receptor-Dependent Induction of Interferons in Protective Immunity to Viruses. Immunological Reviews. 2007;220:225-236.

6. Tassone L, Moratto D, Vermi W, et al. Defect of Plasmacytoid Dendritic Cells in Warts, Hypogammaglobulinemia, Infections, Myelokathexis (Whim) Syndrome Patients. Blood. 2010;116(23):4870-4873.

7. Burton DR. Antibodies, Viruses and Vaccines. Nature Reviews Immunology. 2002;2:706.

8. Klasse PJ. Neutralization of Virus Infectivity by Antibodies: Old Problems in New Perspectives. Advances in Biology. 2014;2014:24.

9. Wetz K. Attachment of Neutralizing Antibodies Stabilizes the Capsid of Poliovirus against Uncoating. Virology. 1993;192(2):465-472.

10. Jayasekera JP, Moseman EA, Carroll MC. Natural Antibody and Complement Mediate Neutralization of Influenza Virus in the Absence of Prior Immunity. Journal of Virology. 2007;81(7):3487-3494.

11. Gerhard W. The Role of the Antibody Response in Influenza Virus Infection. Current topics in microbiology and immunology. 2001;260:171-190.

12. Hashimoto G, Wright PF, Karzon DT. Antibody-Dependent Cell-Mediated Cytotoxicity against Influenza Virus-Infected Cells. J Infect Dis. 1983;148(5):785-794.

13. Park MA, Li JT, Hagan JB, Maddox DE, Abraham RS. Common Variable Immunodeficiency: A New Look at an Old Disease. Lancet. 2008;372(9637):489-502.

14. Cunningham-Rundles C, Bodian C. Common Variable Immunodeficiency: Clinical and Immunological Features of 248 Patients. Clinical Immunology. 1999;92(1):34-48.

15. Eibl MM, Wolf HM. Common Variable Immunodeficiency: Clinical Aspects and Recent Progress in Identifying the Immunological Defect(S). Folia Microbiologica. 1995;40(4):360-366.

16. Reinherz EL, Geha R, Wohl ME, Morimoto C, Rosen FS, Schlossman SF. Immunodeficiency Associated with Loss of T4+ Inducer T-Cell Function. New England Journal of Medicine. 1981;304(14):811-816.

17. Vetrie D, Vorechovsky I, Sideras P, et al. The Gene Involved in X-Linked Agammaglobulinemia Is a Member of the Src Family of Protein-Tyrosine Kinases. Nature. 1993;361(6409):226-233.

18. Adams MJ, Lefkowitz EJ, King AMQ, et al. Ratification Vote on Taxonomic Proposals to the International Committee on Taxonomy of Viruses (2016). Archives of Virology. 2016;161(10):2921-2949.

19. Rager-Zisman B, Allison AC. The Role of Antibody and Host Cells in the Resistance of Mice against Infection by Coxsackie B-3 Virus. Journal of General Virology. 1973;19(3):329-338.

20. MacLennan C, Dunn G, Huissoon AP, et al. Failure to Clear Persistent Vaccine-Derived Neurovirulent Poliovirus Infection in an Immunodeficient Man. Lancet. 2004;363(9420):15091513. 
21. Hidalgo S, Erro MG, Cisterna D, Freire MC. Paralytic Poliomyelitis Caused by a Vaccine-Derived Polio Virus in an Antibody-Deficient Argentinean Child. Pediatric Infectious Disease Journal. 2003;22(6):570-572.

22. Hara M, Saito Y, Komatsu T, et al. Antigenic Analysis of Polioviruses Isolated from a Child with Agammaglobulinemia and Paralytic Poliomyelitis after Sabin Vaccine Administration. Microbiol Immunol. 1981;25(9):905-913.

23. Bellmunt A, May G, Zell R, Pring-Akerblom P, Verhagen W, Heim A. Evolution of Poliovirus Type I During 5.5 Years of Prolonged Enteral Replication in an Immunodeficient Patient. Virology. 1999;265(2):178-184.

24. Abo W, Chiba S, Yamanaka T, Nakao T, Hara M, Tagaya I. Paralytic Poliomyelitis in a Child with Agammaglobulinemia. European Journal of Pediatrics. 1979;132(1):11-16.

25. Kew OM, Sutter RW, Nottay BK, et al. Prolonged Replication of a Type 1 Vaccine-Derived Poliovirus in an Immunodeficient Patient. Journal of Clinical Microbiology. 1998;36(10):28932899.

26. de Silva R, Gunasena S, Ratnayake D, et al. Prevalence of Prolonged and Chronic Poliovirus Excretion among Persons with Primary Immune Deficiency Disorders in Sri Lanka. Vaccine. 2012;30(52):7561-7565.

27. Halsey NA, Pinto J, Espinosa-Rosales F, et al. Search for Poliovirus Carriers among People with Primary Immune Deficiency Diseases in the United States, Mexico, Brazil, and the United Kingdom. Bulletin of the World Health Organization. 2004;82(1):3-8.

28. Tebbens RJD, Pallansch MA, Thompson KM. Modeling the Prevalence of ImmunodeficiencyAssociated Long-Term Vaccine-Derived Poliovirus Excretors and the Potential Benefits of Antiviral Drugs. BMC Infect Dis. 2015;15:18.

29. DeVries AS, Harper J, Murray A, et al. Vaccine-Derived Poliomyelitis 12 Years after Infection in Minnesota. New England Journal of Medicine. 2011;364(24):2316-2323.

30. Sarpong S, Skolnick HS, Ochs HD, Futatani T, Winkelstein JA. Survival of Wild Polio by a Patient with Xla. Annals of Allergy Asthma \& Immunology. 2002;88(1):59-60.

31. Misbah SA, Lawrence PA, Kurtz JB, Chapel HM. Prolonged Fecal Excretion of Poliovirus in a Nurse with Common Variable Hypogammaglobulinemia. Postgraduate Medical Journal. 1991;67(785):301-303.

32. Collett MS, Hincks JR, Benschop K, et al. Antiviral Activity of Pocapavir in a Randomized, Blinded, Placebo-Controlled Human Oral Poliovirus Vaccine Challenge Model. Journal of Infectious Diseases. 2017;215(3):335-343.

33. Rhoden E, Liu HM, Wang-Chern SW, Oberste MS. Anti-Poliovirus Activity of Protease Inhibitor Ag-7404, and Assessment of in Vitro Activity in Combination with Antiviral Capsid Inhibitor Compounds. Antiviral Research. 2013;98(2):186-191.

34. Tyler KL. Rationale for the Evaluation of Fluoxetine in the Treatment of Enterovirus D68Associated Acute Flaccid Myelitis. Jama Neurology. 2015;72(5):493-494.

35. Savilahti E, Klemola T, Carlsson B, Mellander L, Stenvik M, Hovi T. Inadequacy of Mucosal Igm Antibodies in Selective Iga Deficiency - Excretion of Attenuated Polio Viruses Is Prolonged. Journal of Clinical Immunology. 1988;8(2):89-94.

36. Durand P, De Luca G. [Poliomyelitis in Agammaglobulinemic Brothers and in Hypogammaglobulinemic Subjects.]. Minerva Pediatr. 1961;13:1568-1573.

37. Misbah SA, Spickett GP, Ryba PCJ, et al. Chronic Enteroviral Meningoencephalitis in Agammaglobulinemia - Case-Report and Literature-Review. Journal of Clinical Immunology. 1992;12(4):266-270.

38. Rudge $P$, Webster ADB, Revesz $T$, et al. Encephalomyelitis in Primary Hypogammaglobulinaemia. Brain. 1996;119:1-15. 
39. Alborzi A, Hosseini-Nasab A, Zeyaeian M, Sanaei A, Kashef S. A Case of Hypogammaglobulinemia with Enteroviral Meningoencephalitis, Associated with Increased Adenosine Deaminase in Cerebrospinal Fluid. Iranian Journal of Allergy Asthma and Immunology. 2009;8(2):117-119.

40. Wilfert CM, Buckley RH, Mohanakumar T, et al. Persistent and Fatal Central-Nervous-System Echovirus Infections in Patients with Agammaglobulinemia. New England Journal of Medicine. 1977;296(26):1485-1489.

41. Ziegler JB, Penny R. Fatal Echo 30 Virus-Infection and Amyloidosis in X-Linked Hypogammaglobulinemia. Clinical Immunology and Immunopathology. 1975;3(3):347-352.

42. Dwyer JM, Erlendsson K. Intraventricular Gamma-Globulin for the Management of Enterovirus Encephalitis. Pediatric Infectious Disease Journal. 1988;7(5):S30-S33.

43. Halliday E, Winkelstein J, Webster ADB. Enteroviral Infections in Primary Immunodeficiency (Pid): A Survey of Morbidity and Mortality. Journal of Infection. 2003;46(1):1-8.

44. Mantri S, Shah BB. Enterovirus Causes Rapidly Progressive Dementia in a 28-Year-Old Immunosuppressed Woman. Journal of Neurovirology. 2016;22(4):538-540.

45. Radanovic I, Rkman D, Zekan P, Kutlesa M, Barsic B. Chronic Meningoencephalitis Caused by Echo Virus 6 in a Patient with Common Variable Immunodeficiency. Wiener Klinische Wochenschrift. 2018;130(1-2):70-72.

46. Orange JS, Grossman WJ, Navickis RJ, Wilkes MM. Impact of Trough Igg on Pneumonia Incidence in Primary Immunodeficiency: A Meta-Analysis of Clinical Studies. Clinical Immunology. 2010;137(1):21-30.

47. Bernatowska E, Madalinski K. Intravenous Immunoglobulin Therapy of Progressive Encephalitis in X-Linked Hypogammaglobulinemia. Acta Paediatrica Scandinavica. 1987;76(1):155-156.

48. Mease PJ, Ochs HD, Wedgwood RJ. Successful Treatment of Echovirus Meningoencephalitis and Myositis-Fasciitis with Intravenous Immune Globulin Therapy in a Patient with X-Linked Agammaglobulinemia. New England Journal of Medicine. 1981;304(21):1278-1281.

49. Mellouli E, Arrouji Z, Debre M, Bejaoui M. Successful Treatment of Echovirus 27 Meningoencephalitis in Agammaglobulinaemia with Intraventricular Injection of Gammaglobulin. A Case Report. Archives De Pediatrie. 2003;10(2):130-133.

50. Bearden D, Collett M, Quan PL, Costa-Carvalho BT, Sullivan KE. Enteroviruses in X-Linked Agammaglobulinemia: Update on Epidemiology and Therapy. Journal of Allergy and Clinical Immunology-in Practice. 2016;4(6):1059-1065.

51. Sperlich JM, Grimbacher B, Workman S, et al. Respiratory Infections and Antibiotic Usage in Common Variable Immunodeficiency. Journal of Allergy and Clinical Immunology-in Practice. 2018;6(1):159-+.

52. Kainulainen L, Vuorinen T, Rantakokko-Jalava K, Osterback R, Ruuskanen O. Recurrent and Persistent Respiratory Tract Viral Infections in Patients with Primary Hypogammaglobulinemia. Journal of Allergy and Clinical Immunology. 2010;126(1):120-126.

53. Duraisingham SS, Manson A, Grigoriadou S, Buckland M, Tong CYW, Longhurst HJ. Immune Deficiency: Changing Spectrum of Pathogens. Clinical and Experimental Immunology. 2015;181(2):267-274.

54. Nanishi E, Hoshina T, Takada H, et al. A Nationwide Survey of Common Viral Infections in Childhood among Patients with Primary Immunodeficiency Diseases. Journal of Infection. 2016;73(4):358-368.

55. Mieves JF, Wittke K, Freitag H, Volk HD, Scheibenbogen C, Hanitsch LG. Influenza Vaccination in Patients with Common Variable Immunodeficiency (Cvid). Current Allergy and Asthma Reports. 2017;17(11). 
56. Hanitsch LG, Löbel M, Mieves JF, et al. Cellular and Humoral Influenza-Specific Immune Response Upon Vaccination in Patients with Common Variable Immunodeficiency and Unclassified Antibody Deficiency. Vaccine. 2016;34(21):2417-2423.

57. van Assen S, de Haan A, Holvast A, et al. Cell-Mediated Immune Responses to Inactivated Trivalent Influenza-Vaccination Are Decreased in Patients with Common Variable Immunodeficiency. Clinical Immunology. 2011;141(2):161-168.

58. Pedersen G, Halstensen A, Sjursen H, Naess A, Kristoffersen EK, Cox RJ. Pandemic Influenza Vaccination Elicits Influenza-Specific Cd4(+) Th1-Cell Responses in Hypogammaglobulinaemic Patients: Four Case Reports. Scandinavian Journal of Immunology. 2011;74(2):210-218.

59. Shearer WT, Fleisher TA, Buckley RH, et al. Recommendations for Live Viral and Bacterial Vaccines In immunodeficient Patients and Their Close Contacts. Journal of Allergy and Clinical Immunology. 2014;133(4):961-966.

60. Peltola V, Waris M, Kainulainen L, Kero J, Ruuskanen O. Virus Shedding after Human Rhinovirus Infection in Children, Adults and Patients with Hypogammaglobulinaemia. Clinical Microbiology and Infection. 2013;19(7):E322-E327.

61. Ruuskanen O, Waris M, Kainulainen L. Treatment of Persistent Rhinovirus Infection with Pegylated Interferon Alpha 2a and Ribavirin in Patients with Hypogammaglobulinemia. Clinical Infectious Diseases. 2014;58(12):1784-1786.

62. Kainulainen L, Suonpaa J, Nikoskelainen J, et al. Bacteria and Viruses in Maxillary Sinuses of Patients with Primary Hypogammaglobulinemia. Archives of Otolaryngology-Head \& Neck Surgery. 2007;133(6):597-602.

63. Kainulainen L, Nikoskelainen J, Vuorinen T, Tevola K, Liippo K, Ruuskanen O. Viruses and Bacteria in Bronchial Samples from Patients with Primary Hypogammaglobulinemia. American Journal of Respiratory and Critical Care Medicine. 1999;159(4):1199-1204.

64. Schussler E, Beasley MB, Maglione PJ. Lung Disease in Primary Antibody Deficiencies. Journal of Allergy and Clinical Immunology-in Practice. 2016;4(6):1039-1052.

65. Molyneaux PL, Mallia P, Cox MJ, et al. Outgrowth of the Bacterial Airway Microbiome after Rhinovirus Exacerbation of Chronic Obstructive Pulmonary Disease. American Journal of Respiratory and Critical Care Medicine. 2013;188(10):1224-1231.

66. Mallia P, Footitt J, Sotero R, et al. Rhinovirus Infection Induces Degradation of Antimicrobial Peptides and Secondary Bacterial Infection in Chronic Obstructive Pulmonary Disease. American Journal of Respiratory and Critical Care Medicine. 2012;186(11):1117-1124.

67. Tang FSM, Hansbro PM, Burgess JK, Ammit AJ, Baines KJ, Oliver BG. A Novel Immunomodulatory Function of Neutrophils on Rhinovirus-Activated Monocytes in Vitro. Thorax. 2016;71(11):10391049.

68. Robilotti E, Deresinski S, Pinsky BA. Norovirus. Clinical Microbiology Reviews. 2015;28(1):134164.

69. Fankhauser RL, Monroe SS, Noel JS, et al. Epidemiologic and Molecular Trends of "Norwalk-Like Viruses" Associated with Outbreaks of Gastroenteritis in the United States. Journal of Infectious Diseases. 2002;186(1):1-7.

70. Ahmed SM, Hall AJ, Robinson AE, et al. Global Prevalence of Norovirus in Cases of Gastroenteritis: A Systematic Review and Meta-Analysis. Lancet Infectious Diseases. 2014;14(8):725-730.

71. Bresee JS, Widdowson MA, Monroe SS, Glass RI. Foodborne Viral Gastroenteritis: Challenges and Opportunities. Clinical Infectious Diseases. 2002;35(6):748-753.

72. Woodward JM, Gkrania-Klotsas E, Cordero-Ng AYK, et al. The Role of Chronic Norovirus Infection in the Enteropathy Associated with Common Variable Immunodeficiency. American Journal of Gastroenterology. 2015;110(2):320-327. 
73. Brown LAK, Clark I, Brown JR, Breuer J, Lowe DM. Norovirus Infection in Primary Immune Deficiency. Reviews in Medical Virology. 2017;27(3).

74. Woodward J, Gkrania-Klotsas E, Kumararatne D. Chronic Norovirus Infection and Common Variable Immunodeficiency. Clinical and Experimental Immunology. 2017;188(3):363-370.

75. Ruis C, Brown L-AK, Roy S, et al. Mutagenesis in Norovirus in Response to Favipiravir Treatment. New England Journal of Medicine. 2018;379(22):2173-2176.

76. Malamut G, Verkarre V, Suarez F, et al. The Enteropathy Associated with Common Variable Immunodeficiency: The Delineated Frontiers with Celiac Disease. American Journal of Gastroenterology. 2010;105(10):2262-2275.

77. Teahon K, Webster AD, Price AB, Weston J, Bjarnason I. Studies on the Enteropathy-Associated with Primary Hypogammaglobulinemia. Gut. 1994;35(9):1244-1249.

78. Chua I, Standish R, Lear S, et al. Anti-Tumour Necrosis Factor-Alpha Therapy for Severe Enteropathy in Patients with Common Variable Immunodeficiency (Cvid). Clinical and Experimental Immunology. 2007;150(2):306-311.

79. Trials.gov C. Efficacy and Safety of Nitazoxanide for the Treatment of Norovirus. 2018; https://clinicaltrials.gov/ct2/show/NCT03395405. Accessed 21 Nov, 2018.

80. Gairard-Dory AC, Degot T, Hirschi S, et al. Clinical Usefulness of Oral Lmmunoglobulins in Lung Transplant Recipients with Norovirus Gastroenteritis: A Case Series. Transplant Proc. 2014;46(10):3603-3605.

81. van de Ven A, Douma JW, Rademaker C, et al. Pleconaril-Resistant Chronic ParechovirusAssociated Enteropathy in Agammaglobulinaemia. Antiviral Therapy. 2011;16(4):611-614.

82. Jorgensen SF, Reims HM, Frydenlund D, et al. A Cross-Sectional Study of the Prevalence of Gastrointestinal Symptoms and Pathology in Patients with Common Variable Immunodeficiency. American Journal of Gastroenterology. 2016;111(10):1467-1475.

83. Shulzhenko N, Dong X, Vyshenska D, et al. Cvid Enteropathy Is Characterized by Exceeding Low Mucosal Iga Levels and Interferon-Driven Inflammation Possibly Related to the Presence of a Pathobiont. Clinical Immunology. 2018;197:139-153.

84. Nolan N, Halai UA, Regunath H, Smith L, Rojas-Moreno C, Salzer W. Primary Cytomegalovirus Infection in Immunocompetent Adults in the United States - a Case Series. Idcases. 2017;10:123126.

85. Rafailidis PI, Mourtzoukou EG, Varbobitis IC, Falagas ME. Severe Cytomegalovirus Infection in Apparently Immunocompetent Patients: A Systematic Review. Virology Journal. 2008;5.

86. Tahan V, Dobrucali A, Canbakan B, et al. Cytomegalovirus Infection of Gastrointestinal Tract with Multiple Ulcers and Strictures, Causing Obstruction in a Patient with Common Variable Immunodeficiency Syndrome. Digestive Diseases and Sciences. 2000;45(9):1781-1785.

87. Kathi P, Tama M, Reddy V, Kundumadam S, Al-Subee O, Ehrinpreis MN. Acute Gastrointestinal Bleeding Due to Cytomegalovirus Colitis in a Patient with Common Variable Immunodeficiency. Acg Case Reports Journal. 2018;5.

88. Unal B, Bassorgun Cl, Gonulcu SC, Ucar A, Celik F, Elpek GO. Cytomegalovirus Colitis with Common Variable Immunodeficiency and Crohn's Disease. Case Reports in Medicine. 2015.

89. Kralickova P, Mala E, Vokurkova D, et al. Cytomegalovirus Disease in Patients with Common Variable Immunodeficiency: Three Case Reports. International Archives of Allergy and Immunology. 2014;163(1):69-74.

90. Stack E, Washington K, Avant GR, Eisen GM. Cytomegalovirus Enteritis in Common Variable Immunodeficiency. Southern Medical Journal. 2004;97(1):96-101.

91. Zdziarski P, Gamian A, Dworacki G. A Case Report of Lymphoid Intestitial Pneumonia in Common Variable Immunodeficiency: Oligoclonal Expansion of Effector Lymphocytes with Preferential 
Cytomegalovirus-Specific Immune Response and Lymphoproliferative Disease Promotion. Medicine. 2017;96(23).

92. Boeckh M, Stevens-Ayers T, Travi G, et al. Cytomegalovirus (Cmv) DNA Quantitation in Bronchoalveolar Lavage Fluid from Hematopoietic Stem Cell Transplant Recipients with Cmv Pneumonia. The Journal of infectious diseases. 2017;215(10):1514-1522.

93. Cope AV, Sabin C, Burroughs A, Rolles K, Griffiths PD, Emery VC. Interrelationships among Quantity of Human Cytomegalovirus (Hcmv) DNA in Blood, Donor-Recipient Serostatus, and Administration of Methylprednisolone as Risk Factors for Hcmv Disease Following Liver Transplantation. Journal of Infectious Diseases. 1997;176(6):1484-1490.

94. Ochs HD. Common Variable Immunodeficiency (Cvid): New Genetic Insight and Unanswered Questions. Clinical and Experimental Immunology. 2014;178:5-6.

95. Mullighan CG, Read SJ, Bird AG, Kurtz JB, Chapel HM, Welsh KI. Human Cytomegalovirus Infection Is Not Increased in Common Variable Immunodeficiency. Journal of Clinical Immunology. 1996;16(5):272-277.

96. Ramsay I, Gorton RL, Patel M, et al. Transmission of Hepatitis B Core Antibody and Galactomannan Enzyme Immunoassay Positivity Via Immunoglobulin Products: A Comprehensive Analysis. Clinical Infectious Diseases. 2016;63(1):57-63.

97. Greenberger PA, Walker CL, Fitzsimons TE, Roberts M. Hypogammaglobulinemia Associated with Cytomegalovirus Pneumonia. The Journal of Infectious Diseases. 1991;163(3):631-633.

98. Raeiszadeh M, Kopycinski J, Paston SJ, et al. The T Cell Response to Persistent Herpes Virus Infections in Common Variable Immunodeficiency. Clinical and Experimental Immunology. 2006;146(2):234-242.

99. Marashi SM, Raeiszadeh M, Workman S, et al. Inflammation in Common Variable Immunodeficiency Is Associated with a Distinct Cd8(+) Response to Cytomegalovirus. Journal of Allergy and Clinical Immunology. 2011;127(6):1385-U1122.

100. Grunewald JKG, Ridley AJ. Cd73 Represses Pro-Inflammatory Responses in Human Endothelial Cells. Journal of Inflammation-London. 2010;7.

101. Marashi SM, Raeiszadeh M, Enright V, et al. Influence of Cytomegalovirus Infection on Immune Cell Phenotypes in Patients with Common Variable Immunodeficiency. Journal of Allergy and Clinical Immunology. 2012;129(5):1349-U1234.

102. Appay V, Dunbar PR, Callan M, et al. Memory Cd8(+) T Cells Vary in Differentiation Phenotype in Different Persistent Virus Infections. Nature Medicine. 2002;8(4):379-385.

103. Gangemi S, Allegra A, Musolino C. Lymphoproliferative Disease and Cancer among Patients with Common Variable Immunodeficiency. Leuk Res. 2015;39(4):389-396.

104. Kleinman SH, Jhaveri DK, Sterbank J, et al. A Rare Presentation of Ebv Related Lymphoma Leading to a Diagnosis of Hypogammaglobulinemia. Annals of Allergy Asthma \& Immunology. 2013;111(5):A58-A58.

105. Kochin A, Rubinstein A. Case Report of a Patient with Common Variable Immunodeficiency (Cvid), Mannose Binding Lectin Deficiency with Persistent Ebv Infection and Recurrent Ebv Induced Leiomyosarcoma. Annals of Allergy Asthma \& Immunology. 2013;111(5):A87-A87.

106. Gibert MP, Alsina L, Munoz MTG, et al. Non-Hodgkin Lymphoma in Pediatric Patients with Common Variable Immunodeficiency. European Journal of Pediatrics. 2015;174(8):1069-1076.

107. Cunninghamrundles C, Lieberman P, Hellman G, Chaganti RSK. Non-Hodgkin Lymphoma in Common Variable Immunodeficiency. American Journal of Hematology. 1991;37(2):69-74.

108. Sander CA, Medeiros L, Weiss LM, Yano T, Sneller MC, Jaffe ES. Lymphoproliferative Lesions in Patients with Common Variable Immunodeficiency Syndrome. American Journal of Surgical Pathology. 1992;16(12):1170-1182. 
109. Bates CA, Ellison MC, Lynch DA, Cool CD, Brown KK, Routes JM. Granulomatous-Lymphocytic Lung Disease Shortens Survival in Common Variable Immunodeficiency. Journal of Allergy and Clinical Immunology. 2004;114(2):415-421.

110. Wheat $\mathrm{WH}, \mathrm{Cool} \mathrm{CD}$, Morimoto Y, et al. Possible Role of Human Herpesvirus 8 in the Lymphoproliferative Disorders in Common Variable Immunodeficiency. Journal of Experimental Medicine. 2005;202(4):479-484.

111. Soden JS, Narkewicz MR, Haas JE, Sokol RJ. Hepatic Veno-Occlusive Disease and Human Herpes Virus 7 Infection in Primary Agammaglobulinemia. Journal of Pediatrics. 2009;154(2):299-302.

112. Dray X, Treton X, Mazeron MC, et al. Herpes Simplex Virus Type 1 Colitis in a Patient with Common Variable Immunodeficiency Syndrome. European Journal of Gastroenterology \& Hepatology. 2006;18(5):541-544.

113. Hanafiah KM, Groeger J, Flaxman AD, Wiersma ST. Global Epidemiology of Hepatitis C Virus Infection: New Estimates of Age-Specific Antibody to Hcv Seroprevalence. Hepatology. 2013;57(4):1333-1342.

114. Yap PL, McOmish F, Webster ADB, et al. Hepatitis-C Virus Transmission by Intravenous Immunoglobulin. Journal of Hepatology. 1994;21(3):455-460.

115. Bjoro K, Skaug K, Haaland T, Froland SS. Long-Term Outcome of Chronic Hepatitis C Virus Infection in Primary Hypogammaglobulinaemia. QJM-Mon J Assoc Physicians. 1999;92(8):433441.

116. Bjoro K, Froland SS, Yun ZB, Samdal HH, Haaland T. Hepatitis-C Infection in Patients with Primary Hypogammaglobulinemia after Treatment with Contaminated Immune Globulin. New England Journal of Medicine. 1994;331(24):1607-1611.

117. Razvi S, Schneider L, Jonas MM, Cunningham-Rundles C. Outcome of Intravenous Immunoglobulin-Transmitted Hepatitis C Virus Infection in Primary Immunodeficiency. Clinical Immunology. 2001;101(3):284-288.

118. Chapel HM, Christie JML, Peach V, Chapman RWG. Five-Year Follow-up of Patients with Primary Antibody Deficiencies Following an Outbreak of Acute Hepatitis C. Clinical Immunology. 2001;99(3):320-324.

119. Sierra FJ, GilAguado A, Echevarria JM, et al. Hcv and Hypogammaglobulinemia. Journal of Hepatology. 1997;26(5):1158-1159.

120. Quinti I, Pandolfi F, Paganelli R, et al. Hepatitis C Virus Infection in Italian Patients with Hypogammaglobulinemia. Clinical Therapeutics. 1996;18:96-107.

121. Fattovich G, Giustina G, Degos F, et al. Morbidity and Mortality in Compensated Cirrhosis Type C: A Retrospective Follow-up Study of 384 Patients. Gastroenterology. 1997;112(2):463-472.

122. Quinti I, Pandolfi F, Paganelli R, et al. Hcv Infection in Patients with Primary Defects of Immunoglobulin Production. Clinical and Experimental Immunology. 1995;102(1):11-16.

123. Kao JH, Chen PJ, Lai MY, et al. Mixed Infections of Hepatitis-C Virus as a Factor in Acute Exacerbations of Chronic Type-C Hepatitis. Journal of Infectious Diseases. 1994;170(5):11281133.

124. Widell A, Mansson S, Persson NH, Thysell H, Hermodsson S, Blohme I. Hepatitis-C Superinfection in Hepatitis-C Virus (Hcv)-Infected Patients Transplanted with an Hcv-Infected Kidney. Transplantation. 1995;60(7):642-647.

125. Tong MJ, Nies KM, Redeker AG. Rapid Progression of Chronic Active Type-B Hepatitis in a Patient with Hypogammaglobulinemia. Gastroenterology. 1977;73(6):1418-1421.

126. Tsutsumi Y, Yamamoto Y, Ito S, et al. Hepatitis B Virus Reactivation with a Rituximab-Containing Regimen. World journal of hepatology. 2015;7(21):2344-2351.

127. Coiffier B. Hepatitis B Virus Reactivation in Patients Receiving Chemotherapy for Cancer Treatment: Role of Lamivudine Prophylaxis. Cancer Investigation. 2006;24(5):548-552. 
128. Webster ADB, Brown D, Franz A, Dusheiko G. Prevalence of Hepatitis C in Patients with Primary Antibody Deficiency. Clinical and Experimental Immunology. 1996;103(1):5-7.

129. Slade HB. Human-Immunoglobulins for Intravenous Use and Hepatitis-C Viral Transmission. Clinical and Diagnostic Laboratory Immunology. 1994;1(6):613-619.

130. Ward C, Lucas M, Piris J, Collier J, Chapel H. Abnormal Liver Function in Common Variable Immunodeficiency Disorders Due to Nodular Regenerative Hyperplasia. Clinical and Experimental Immunology. 2008;153(3):331-337.

131. Ankcorn M, Moreira F, ljaz S, et al. Absence of Persistent Hepatitis E Virus Infection in AntibodyDeficient Patients Is Associated with Transfer of Antigen-Neutralizing Antibodies from Immunoglobulin Products. The Journal of Infectious Diseases. 2018:jiy504-jiy504.

132. Fremond ML, Perot $P$, Muth E, et al. Next-Generation Sequencing for Diagnosis and Tailored Therapy: A Case Report of Astrovirus-Associated Progressive Encephalitis. Journal of the Pediatric Infectious Diseases Society. 2015;4(3):E53-E57.

133. Wilson MR, Suan D, Duggins A, et al. A Novel Cause of Chronic Viral Meningoencephalitis: Cache Valley Virus. Annals of Neurology. 2017;82(1):105-114.

134. Bucciol G, Moens L, Payne K, et al. Chronic Aichi Virus Infection in a Patient with X-Linked Agammaglobulinemia. Journal of Clinical Immunology. 2018;38(7):748-752. 


\section{Figure Legend}

\section{Figure 1. Mechanisms of Antibody mediated Viral Immunity}

a. Neutralising antibodies bind to surface of free virus and may inactivate viral proteins or induce conformational changes. Through activation of complement direct virolysis of enveloped viruses can occur. b. Bound antibody prevents infection of target cell, and instead promotes agglutination facilitating uptake by professional phagocytes (c.) where virus is destroyed in activated phagolysosomes. d. Antibody-bound viral particles absorbed in endosome are unable to uncoat. e. Neutralising antibodies prevent release of progeny virus from infected cell preventing ongoing infection. f. Non-neutralising antibodies bind viral proteins expressed on infected cell and engage Fc receptors on cytotoxic cells. Infected cells are cleared by Antibodydependent cytotoxicity CC via release cytotoxic granules and reactive oxygen species. 
Figure 1.

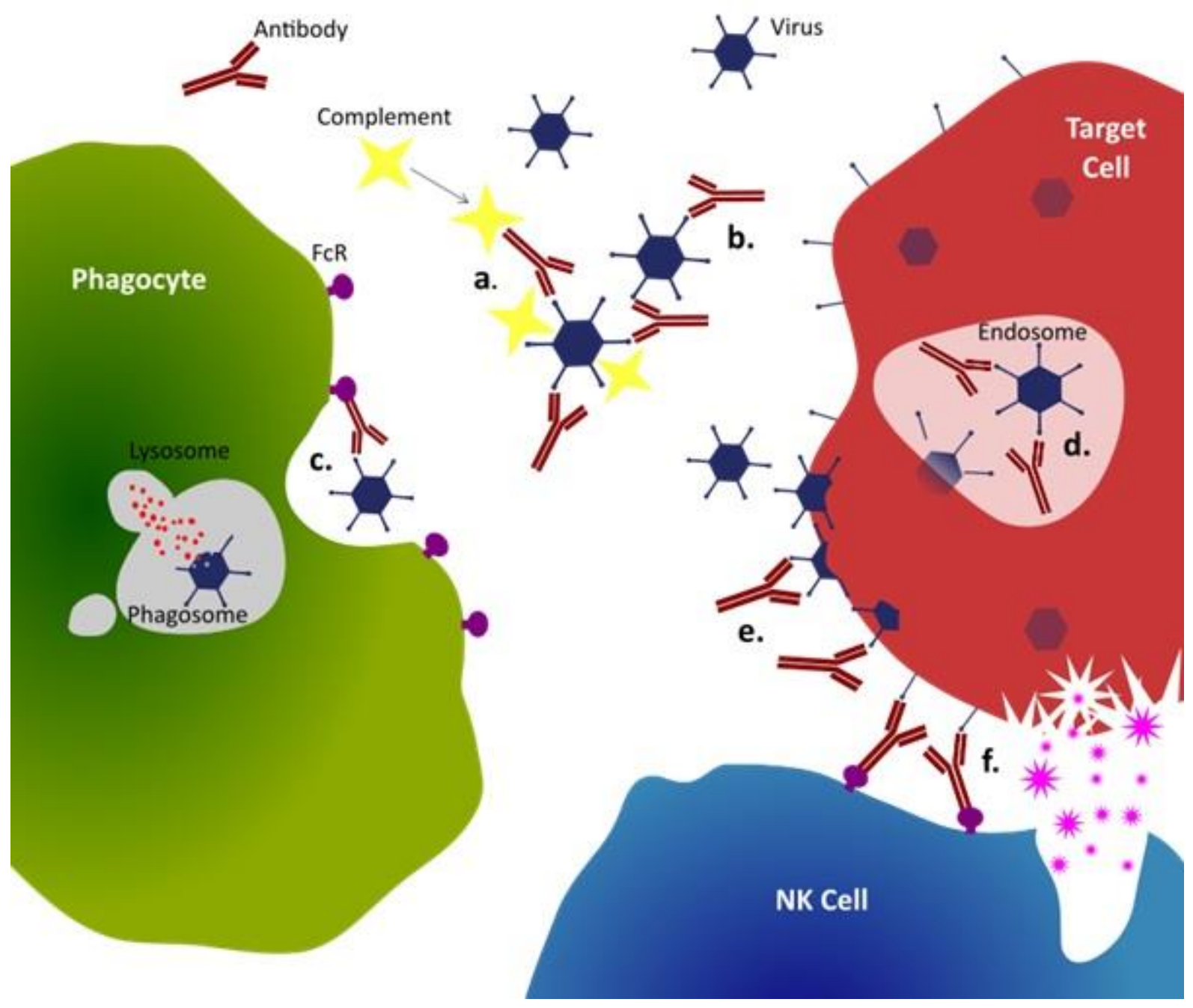


Table1. Case Studies and Series of Chronic Enterovirus Meningoencephalitis in Primary Antibody Deficiency Syndromes

\begin{tabular}{|c|c|c|c|c|c|c|c|}
\hline \multirow[b]{2}{*}{ Author/Year } & \multirow[b]{2}{*}{$\mathbf{N}$} & \multirow[b]{2}{*}{ Diagnosis } & \multirow[b]{2}{*}{ Presentation } & \multirow[b]{2}{*}{ Virus } & & \multirow[b]{2}{*}{ Outcome } \\
\hline & & & & & Prior & for CEMA & \\
\hline $\begin{array}{l}\text { Alborzi et al. } \\
2009 \text { (38) }\end{array}$ & 1 & $\mathrm{AG}^{+}$ & 12yr male. Headache vomiting and fever. & Enterovirus & IVIg & High Dose IVIg & Clinical Improvement. \\
\hline $\begin{array}{l}\text { Bearden et al. } \\
2016 \text { (49) }\end{array}$ & 1 & XLA & $\begin{array}{l}\text { 15mths male. Slowly progressive encephalopathy } \\
\text { and ataxia. }\end{array}$ & Coxsackievirus B5 & IVIg & $\begin{array}{l}\text { High Dose IVIg, Interferon Alpha } \\
\text { 2b, Cidofovir. Pocapavir }\end{array}$ & $\begin{array}{l}\text { Motor and cognitive } \\
\text { stable deficits }\end{array}$ \\
\hline $\begin{array}{l}\text { Bernatowska et } \\
\text { al. } 1987 \text { (46) }\end{array}$ & 1 & XLA & 9yr male. Headache, convulsions and leg pain. & Echovirus 17 & FFP & High Dose IVIg & $\begin{array}{l}\text { Improvement at } 6 \mathrm{mths} \\
\text { continued at } 2 \text { yrs }\end{array}$ \\
\hline $\begin{array}{l}\text { Dwyer et al. } \\
1988(41)\end{array}$ & 3 & $\begin{array}{l}\text { XLA }(n=2) \\
\text { HIgM }\end{array}$ & $\begin{array}{l}\text { 9yr male. Seizures and hemiparesis } \\
\text { 4yr male. Headaches and behavioral problems. } \\
\text { 9yr male. Cognitive impairment, behavioral issues }\end{array}$ & $\begin{array}{c}\text { Echovirus } 5 \\
\text { Echovirus } 11 \quad(n=2)\end{array}$ & IMlg & Intrathecal Immunoglobulin & $\begin{array}{l}\text { Improvement }(n=2) \\
\text { Stable impairment at } \\
12 \text { mths }(n=1)\end{array}$ \\
\hline $\begin{array}{l}\text { Mantri and Shah } \\
2016 \text { (43) }\end{array}$ & 1 & CVID & $\begin{array}{l}\text { 28yr female. Progressive confusion and memory } \\
\text { loss. }\end{array}$ & Coxsackievirus B3 & IVIg & IVIg & $\begin{array}{l}\text { Death from middle } \\
\text { cerebral artery } \\
\text { infarction }\end{array}$ \\
\hline $\begin{array}{l}\text { Mease et al. } \\
1981 \text { (47) }\end{array}$ & 1 & XLA & $\begin{array}{l}\text { 32yr male. Progressive muscle weakness, } \\
\text { dysphasia and oedema. }\end{array}$ & Echovirus 11 & IMlg & High Dose IVIg & Resolution at $11 \mathrm{mths}$ \\
\hline $\begin{array}{l}\text { Mellouli et al. } \\
2003 \text { (48) }\end{array}$ & 1 & $\mathrm{AG}^{+}$ & 3yr male. Aphasia and behavioral disturbance. & Echovirus 27 & IVIg & Intrathecal Immunoglobulin & $\begin{array}{l}\text { Clinical Improvement } \\
\text { by } 21 \mathrm{mths}\end{array}$ \\
\hline $\begin{array}{l}\text { Mishbah et al } \\
1992(36)\end{array}$ & 1 & XLA & $\begin{array}{l}\text { 11yr male. Behavioral issues, apathy, headache } \\
\text { and gait disturbance. }\end{array}$ & Echovirus 11 & IVlg & $\begin{array}{l}\text { High Dose IVIg. Ribavirin } 6 \text { weeks } \\
\qquad 15 \mathrm{mg} / \mathrm{kg}\end{array}$ & $\begin{array}{l}\text { Death } 5 \text { mths after } \\
\text { presentation }\end{array}$ \\
\hline $\begin{array}{l}\text { Radanovic et al. } \\
\qquad 2018 \text { (44) }\end{array}$ & 1 & CVID & $\begin{array}{l}\text { 42yr male. Headache, gait instability and } \\
\text { intermittent dysphasia }\end{array}$ & Echovirus 6 & IVIg & Pleconaril & $\begin{array}{l}\text { Improved with ongoing } \\
\text { weakness at } 7 \mathrm{mths}\end{array}$ \\
\hline $\begin{array}{l}\text { Rudge et al. } \\
1996 \text { (37) }\end{array}$ & 13 & $\begin{array}{l}\mathrm{XLA}(n=7) \\
\operatorname{CVID}(n=6)\end{array}$ & $\begin{array}{l}\text { 44yr female with myelopathy } \\
\text { Four males (aged } 13 \text { to } 56 \text { yrs) with mixed } \\
\text { myelopathy and encephalopathy } \\
\text { Seven males and one female (aged } 6 \text { to } 40 \mathrm{yrs} \text { ) } \\
\text { with encephalopathy }\end{array}$ & $\begin{array}{l}\text { Echovirus } 3 \\
\text { Echovirus } 11 \\
\text { Echovirus } 17 \\
\text { Enterovirus }(n=4) \\
\text { Unknown }(n=6)\end{array}$ & $\begin{array}{l}\text { IMIg }(n=9) \\
\operatorname{IVIg}(n=1) \\
\text { FFP }(n=2) \\
\text { None }(n=1)\end{array}$ & $\begin{array}{l}\text { High dose IVIg }(n=8) \text {. } \\
\text { Hyperimmune human and sheep } \\
\text { serum }(n=1) \\
\text { FFP }(n=2) \\
\text { Intrathecal Immunoglobulin }(n=1) \\
\text { Intrathecal Alpha IFN } 1(n=1)\end{array}$ & $\begin{array}{l}\text { Death in } 11 \\
\text { (6 from confirmed viral } \\
\text { infection) }\end{array}$ \\
\hline $\begin{array}{l}\text { Wilfert et al. } \\
1977 \text { (39) }\end{array}$ & 5 & $\begin{array}{l}A^{+}(n=4) \\
X L A(n=1)\end{array}$ & $\begin{array}{c}\text { 24yr male. Muscle weakness and oedema. } \\
42 \mathrm{mths} \text { female. Behavioral changes, lethargy. } \\
12 \mathrm{yr} \text { male. Reduced muscle mass, contractures } \\
\text { 7yr male. Progressive headaches. } \\
\text { 3yr male. Muscle wasting of extremities }\end{array}$ & $\begin{array}{c}\text { Echovirus } 9(n=2) \\
\text { Echovirus } 30(n=3) \\
\text { Echovirus } 33\end{array}$ & IMlg & IVlg & $\begin{array}{c}\text { Stable }(n=2) \\
\text { Improvement }(n=1) \\
\text { Progressive }(n=1) \\
\text { Death after } 7 \text { wks }(n=1)\end{array}$ \\
\hline $\begin{array}{l}\text { Ziegler and Penny } \\
1975(40)\end{array}$ & 1 & XLA & 7yr male. Fever, headache and altered sensation & Echovirus 30 & IMlg & IMlg & Death after 9 mths \\
\hline
\end{tabular}

CVID - Common Variable Immunodeficiency. XLA - X-Linked Agammaglobulinaemia. HIgM - Hyper IgM Syndrome. AG - Agammaglobulinaemia IFN- Interferon. IVIg - Intravenous Immunoglobulin. IMIg - Intramuscular Immunoglobulin. FFP - Fresh Frozen Plasma.

+ Formal diagnosis not reported. 
Table 2. Case Series Reports on Hepatitis C Virus Infection in Primary Antibody Deficiency Syndromes.

\begin{tabular}{|c|c|c|c|c|c|c|c|}
\hline Author/Year & $\mathbf{N}$ & Diagnosis & $\begin{array}{l}\text { Period of } \\
\text { Observation }\end{array}$ & Treatment & Viral Clearance & $\begin{array}{l}\text { Cirrhosis } \\
\text { Prevalence }\end{array}$ & Mortality \\
\hline $\begin{array}{l}\text { Bjoro et al. } \\
1994 \text { (107) }\end{array}$ & 18 & $\begin{array}{l}\text { CVID }(n=5) \\
\text { XLA }(n=6) \\
\text { CH }(n=5) \\
\operatorname{HIgM~}(n=2)\end{array}$ & Not reported & IFN Monotherapy $(n=10)$ & Clearance $(n=1)^{+}$ & $33.3 \%(6 / 18)$ & $\begin{array}{l}\text { Overall 20\% (4/20) } \\
\text { CVID } 40.0 \%(2 / 5) \\
\text { XLA } 16.7 \%(1 / 6)\end{array}$ \\
\hline $\begin{array}{l}\text { Bjoro et al. } \\
1999 \text { (106) }\end{array}$ & 20 & $\begin{array}{l}\text { CVID }(n=6) \\
\text { XLA }(n=6) \\
\text { CH }(n=6) \\
\text { HIgM }(n=2)\end{array}$ & 13 years & $\begin{array}{l}\text { IFN Monotherapy }(n=10) \\
\text { IFN and Ribavirin }(n=7) \\
\text { Liver transplantation }(n=2)\end{array}$ & $\begin{array}{l}\text { Unsustained }(n=3) \\
\text { Sustained }(n=5)\end{array}$ & $70.5 \%(12 / 17)$ & $\begin{array}{c}\text { Overall 55\% (11/20) } \\
\text { CVID 83.3\% (5/6) } \\
\text { XLA 50\% (3/6) } \\
\text { CH 33.3\% (2/6) } \\
\text { HIgM 50\% (1/2) }\end{array}$ \\
\hline $\begin{array}{l}\text { Chapel et al. } \\
2001 \text { (109) }\end{array}$ & 25 & $\begin{array}{l}\text { CVID }(n=16) \\
\text { IgG def. }(n=7) \\
\text { XLA }(n=2)\end{array}$ & 5 years & $\begin{array}{l}\text { IFN Monotherapy }(n=17) \\
\text { IFN and Ribavarin }(n=3) \\
\text { Liver Transplantation }(n=2)\end{array}$ & $\begin{array}{c}\text { Spontaneous }(n=2) \\
\text { Treated Sustained }(n=7)\end{array}$ & $24.0 \%(6 / 25)$ & $\begin{array}{l}\text { Overall } 32.0 \%(8 / 25) \\
\quad \text { XLA } 50 \%(1 / 2) \\
\text { CVID } 31.25 \%(6 / 16) \\
\text { IgG def } 14.3(1 / 7)\end{array}$ \\
\hline $\begin{array}{l}\text { Quinti et al. } \\
1996 \text { (111) }\end{array}$ & 18 & $\begin{array}{c}\text { CVID }(n=15) \\
\text { HIgM }(n=2) \\
\text { IgG def. }(n=2)\end{array}$ & Not reported & Not Reported & Not Reported & $11.1 \%(2 / 18)$ & 0 \\
\hline $\begin{array}{l}\text { Razvi et al. } \\
2001 \text { (108) }\end{array}$ & 58 & $\begin{array}{l}\text { CVID }(n=40) \\
\text { XLA }(n=10) \\
\text { IgG def. }(n=7) \\
\text { Other }(n=1)\end{array}$ & $\begin{array}{l}\text { Variable } \\
\text { (5 to } 9 \text { years) }\end{array}$ & $\begin{array}{l}\text { IFN Monotherapy }(n=22) \\
\text { IFN and Ribavarin }(n=8) \\
\text { Liver Transplantation }(n=4)\end{array}$ & $\begin{array}{l}\text { Clearance }(n=16) \\
\text { Treated Patients }(n=11) \\
\text { Untreated Patients }(n=5)\end{array}$ & Not reported & $\begin{array}{l}\text { Overall } 17.2 \% \\
(10 / 58) \text { CVID } 23 \% \\
\text { All others } 8 \%\end{array}$ \\
\hline $\begin{array}{l}\text { Sierra et al. } \\
1997(110)\end{array}$ & 8 & $\begin{array}{c}\operatorname{CVID}(n=6) \\
\operatorname{XLA}(n=1) \\
\operatorname{HIgM}(n=1)\end{array}$ & Not reported & IFN Monotherapy $(n=3)$ & None & $62.0 \%(5 / 8)$ & 0 \\
\hline
\end{tabular}

CVID - Common Variable Immunodeficency. XLA - X-Linked Agammaglobulinaemia. CH - Congenital Hypogammaglobulinaemia. HIgM - Hyper IgM Syndrome.

IgG def. - IgG Deficiency Syndrome. IFN- Interferon.

+ Unable to specify whether sustained clearance as only one sample available before patient committed suicide 